\title{
GSTT2 Gene
}

National Cancer Institute

\section{Source}

National Cancer Institute. GSTT2 Gene. NCI Thesaurus. Code C158388.

This gene is involved in glutathione conjug ation. 